\title{
In memoriam, Francisco Javier Ibisate
}

Luis Alvarenga

En una coincidencia desafortunada, El Salvador perdió en el mes de abril a dos hombres que han encarnado lo mejor de sus valores intelectuales, es decir, la inteligencia puesta al servicio de las mayorías. El uno, a través de la palabra poética; el otro, a través del análisis académico. Ovidio Villafuerte y Francisco Javier Ibisate son estos dos hombres, que recordamos con cariño y valoramos su obra en sus alcances humanísticos. Estas líneas van dedicadas al segundo de ellos, al padre Ibisate y a su herencia intelectual.

El padre Ibisate vino al país hace cuarenta años, los mismos que cumplió nuestro novelista Miguel Ángel Espino de haber muerto. Es uno de los símbolos del compromiso de la UCA, universidad a la cual sirvió con suma dedicación, desde su labor como maestro, como rector, como analista de la realidad salvadoreña, pero sobre todo, como ser humano. Consciente de que la labor universitaria sólo cobra sentido si sirve para que el pueblo tenga herramientas para entender su realidad y transformarla, el padre lbisate se volcó al análisis de esa realidad a través del lente de la disciplina intelectual de la cual era un gran conocedor: la economía.

Tendemos a pensar que la economía es una ciencia abstraída del ser humano. La aparente frialdad y exactitud de las fórmulas e indicadores económicos nos hacen olvidar que la economía, desde sus orígenes, tiene una estrecha relación con la vida humana en sus aspectos más fundamentales. Desde su etimología griega, oikos, casa y nomos, orden, organización, el ordenamiento de los recursos de la casa, de la sociedad, que es, o debiera ser, la casa de todos, la economía está llamada a responder por la pregunta: ¿cómo deberían de estar organizados los recursos de la sociedad para satisfacer las necesidades fundamentales de todos sus miembros? Lo que ocurre es que impera cierta concepción de economia, rodeada de un halo de impenetrabilidad, que la hace parecer ajena a los seres humanos a los cuales se debe.

El padre lbisate no cayó presa de esta mistificación. Al contrario, supo la razón de ser de la economía y actuó en consecuencia. Sus análisis de la coyuntura económica nacional, sus cátedras y, ya en estos últimos me- 
ses, sus amenas charlas sobre economía a través de la radio universitaria eran algunos de los cauces que tomaba su compromiso académico.

Al sacerdote jesuita que, hace cuarenta años, se hizo una sola carne y un solo corazón con el pueblo salvadoreño, le debemos también la creación de la revista Realidad económica y social, que nació, a iniciativa suya, como un boletín de coyuntura económica en los años ochenta, cuando la situación del país hacía imperativo - y sigue siéndolo- volver asequible el análisis académico de la realidad al público más amplio. Realidad económica y social se convirtió posteriormente en la revista Realidad. El padre Ibisate fue miembro de su consejo editorial, al cual siempre aportó importantes ideas, además de sus artículos, en los cuales le dio un seguimiento sistemático a problemas acuciantes como las implicaciones de las cumbres mundiales, los problemas de la globalización, el neoliberalismo, el terrorismo de los grandes poderes contra los países pobres, entre otros. Se caracterizó por ser un entusiasta promotor del trabajo investigativo de los estudiantes de Economía. Si se encuentran en las páginas de esta revista algunas de las tesis de grado de Economía, ello se debió a que el padre Ibisate seleccionaba aquellas que, a su juicio, podian ser interesantes para el debate de los problemas nacionales e internacionales.

Francisco Javier lbisate fue el economista que creía en la humanidad. El fruto de su inteligencia y de su amor por esa humanidad, que para él tenía los rostros reales de los pobres, está en todo lo que hizo por la UCA y por el país. 